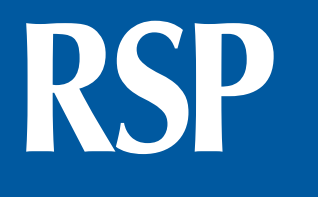

http://www.rsp.fsp.usp.br/

Revista de Saúde Pública

\title{
Prevalence and factors associated to chronic kidney disease in older adults
}

\author{
Thatiana Lameira Maciel Amaral' iD, Cledir de Araújo Amaral" iD, Maurício Teixeira Leite de \\ Vasconcellos"II (iD, Gina Torres Rego Monteiro ${ }^{1,1 \mathrm{~V}}$ (iD \\ ' Universidade Federal do Acre. Centro de Ciências da Saúde e do Desporto. Programa de Pós-Graduação em \\ Saúde Coletiva. Rio Branco, AC, Brasil \\ "Instituto Federal de Educação, Ciência e Tecnologia do Acre. Campus Rio Branco. Rio Branco, AC, Brasil \\ I"I Fundação Instituto Brasileiro de Geografia e Estatística. Escola Nacional de Ciências Estatísticas. Rio de Janeiro, \\ RJ, Brasil \\ Iv Fundação Oswaldo Cruz. Escola Nacional de Saúde Pública Sérgio Arouca. Rio de Janeiro, RJ, Brasil
}

Correspondence:

Thatiana Lameira Maciel Amaral Campus Universitário

Centro de Ciências da Saúde e do Desporto

BR 364 km 4 Distrito Industrial

Caixa postal 500

69920-900 Rio Branco, AC, Brasil

E-mail: thatianalameira27@gmail.com

Received: Mar 31, 2018

Approved: Jun 13, 2018

How to cite: Amaral TLM, Amaral CA, Vasconcellos MTL, Monteiro GTR. Prevalence and factors associated to chronic kidney disease in older adults. Rev Saude Publica. 2019;53:44.

Copyright: This is an open-access article distributed under the terms of the Creative Commons Attribution License, which permits unrestricted use, distribution, and reproduction in any medium, provided that the original author and source are credited.

\section{ABSTRACT}

OBJECTIVE: To verify the prevalence of chronic kidney disease and the factors associated to it in older adults ( $\geq 60$ years).

METHODS: This is a population-based research conducted in 2014, involving 1,016 older adults living in urban and rural areas of the municipality of Rio Branco, Acre. Chronic kidney disease was defined by glomerular filtration rate $<60 \mathrm{ml} / \mathrm{min} / 1.73 \mathrm{~m}^{2}$, estimated by the equations of the Chronic Kidney Disease Epidemiology Collaboration, and the presence of albuminuria $>29 \mathrm{mg} / \mathrm{g}$. Association measure were estimated by gross and adjusted odds ratio (OR), with a confidence level of $95 \%$ (95\% CI).

RESULTS: The overall prevalence of chronic kidney disease was $21.4 \%$ in older adults, with the associated factors age, diabetes $(\mathrm{OR}=3.39$; $95 \% \mathrm{CI} 2.13-5.40)$, metabolic syndrome $(\mathrm{OR}=2.49$; 95\%CI 1.71-3.63), self-assessment of poor health $(\mathrm{OR}=1.79$; $95 \% \mathrm{CI} 1.10-2.91)$, arterial hypertension $(\mathrm{OR}=1.82 ; 95 \% \mathrm{CI} 1.04-3.19)$ and obesity ( $\mathrm{OR}=1.69 ; 95 \% \mathrm{CI} 1.02-2.80)$.

CONCLUSIONS: The prevalence of chronic kidney disease was high in older adults, being associated with age, self-assessment of health as bad or very bad, obesity, diabetes and metabolic syndrome.

DESCRIPTORS: Aged. Renal Insufficiency, Chronic, epidemiology. Risk Factors. Comorbidity. Health Surveys. 


\section{INTRODUCTION}

The pattern of morbimortality due to chronic kidney disease (CKD) in underdeveloped and developing countries is changing due to the transition of infectious diseases to chronic non-communicable diseases ${ }^{1}$. Prevalence projections of CKD in the U.S. for 2020 and 2030, between individuals over 30 years, estimate that the disease will go from $13.2 \%$ in 2010 to $14.4 \%$ in 2020 and to $16.7 \%$ in $2030^{2}$.

The prevalence of CKD changes with age, reaching higher values among older people, and may vary from $25.1 \%$ in Nicaragua, in the age group of 60 to 70 years $^{3}$, to $30.8 \%$ in Canada, among those aged $\geq 65$ years $^{4}$. The reduction in the glomerular filtration rate (GFR) for less than $60 \mathrm{ml} / \mathrm{min} / 1.73 \mathrm{~m}^{2}$ might be attributed to aging, which causes progressive structural and functional changes in the kidneys, or as consequence of the presence of comorbidities and of the exposition of risk factors throughout life ${ }^{5}$.

Among older adults, the presence of CKD represents an increased risk for multiple events adverse to health that may culminate in death, and the early detection of the reduced GFR and albuminuria is important to assist in the therapeutic decision-making and consequent reduction of complications ${ }^{6}$. Thus, this study aimed to estimate the prevalence of CKD and the factors associated to it in older adults (60 years or more), using part of the data from the Estudo das Doenças Crônicas (Edoc - Study of Chronic Diseases).

\section{METHODS}

The Edoc is composed of two household surveys: the Edoc-A, on adults (18 to 59 years-old), and the Edoc-I, on older adults (60 years or more), all living in Rio Branco, Acre. Individuals with cognitive impairments that could preclude communication or understanding of the questions were excluded. Sampling plans were selected in two stages, census enumerations areas (CEAs) and households, being the first common to the two researches. The CEAs were selected with probability proportional to the number of private households in the 2010 Demographic Census (CD2010) of the Brazilian Institute of Geography and Statistics (IBGE). The households were selected by systematic sampling with random starts and distinct ranges per survey. In the households selected for Edoc-I, all the older adult residents were interviewed.

The sample size was estimated considering the prevalence of renal function changes of $40 \%$ in older adults ${ }^{7}$, with confidence level of $95 \%$ and absolute error of $3 \%$ for the simple random sampling of proportions. Considering that the sampling plan is conglomerated by CEA, a sampling plan effect of 1.95 was arbitrated to determine the sample size, which received an increase of $12.5 \%$ to compensate the expected non-responses. This procedure resulted in a sample of 1,148 older adults. By dividing this sample size by the number of older adults per household, according to CD2010, and by defining the selection of 73 households per CEA, a sample size of CEAs of 40 was obtained. The effective sample was 1,016 older adults.

The sampling weights were calculated by the inverse of the inclusion probabilities in each stage and were subsequently calibrated for populational data by sex and age groups, using a post-stratification estimator, in order to address these typical biases of the household surveys and to correct differential non-responses ${ }^{8}$. The population data used in the calibration of the sampling weights were estimated for July 1, 2014, using the linear trend method $^{9}$ that the IBGE applies in its population estimations per municipality. This study included all who performed laboratory assessments of serum creatinine, that is, 983 older adults ( 578 women and 405 men), that correspond to a subsample of complete information on the topic. For more details about the sampling plan of the Edoc, estimation and calibration of sample weights and subsamples, see the article by Amaral et al. ${ }^{10}$. 
A total of 33 participants were excluded from the analysis of renal function due to the lack of information on serum creatinine. Each household with a participant resident filled a form containing general information on housing, sanitation and family. Individually, a structured form was used in thematic modules with socioeconomic, demographic, behavioral and health information.

In the physical assessment, the anthropometric data included the measurement of weight, height and circumferences of the waist, hips, arm and calf, all in duplicate, and the average of the measurements was considered.

Blood pressure (BP) was measured according to the protocol recommended by the Brazilian Society of Cardiology, which recommends measuring 30 minutes or more after the last drank dose of caffeine or smoked cigarette, in triplicate: one after five minutes of initial rest and two others in intervals of two minutes ${ }^{11}$.

The biological material was analyzed in the same laboratory to ensure the standardization of methods. Blood samples were obtained by peripheral blood collection, with prior antisepsis of the antecubital fossa of the participants. The serum extracted was stored for biochemical dosage of triglycerides, total cholesterol and fractions: high-density lipoprotein (HDL) and low-density lipoprotein (LDL). Serum creatinine was dosed by traceable enzymatic method of isotope dilution mass spectrometry (IDMS) in an automatic analyzer (Labmax 240 Premium). To analyze serum glycemia, a $4 \mathrm{ml}$ blood sample was used, stored in a vacuum tube containing $2 \mathrm{mg} / \mathrm{ml}$ of sodium fluoride centrifuged before analysis. The serum glycemia was dosed by the glucose oxidase method (Labtest Diagnostica).

For the urine sample, $50 \mathrm{ml}$ of the midstream of first morning urine of each individual were collected, subsequently processed for physicochemical and microscopic analysis of the sediment.

Urinary creatinine was dosed by the enzymatic Trinder method (Kit Creatinina Enzimática, Labtest), and albuminuria by the immunoturbidimetric method (Kit Turbiquest Plus, Labtest). Albuminuria is defined with a ratio of albumin to creatinine of $30 \mathrm{mg} / \mathrm{g}$ or more, being the value of 30 to 299 considered A2, or moderately increased, and the value $\geq 300 \mathrm{mg} / \mathrm{g}$ considered A3, or markedly increased.

The systemic arterial hypertension (SAH) was defined as diastolic blood pressure (DBP) $\geq 90 \mathrm{mmHg}$, systolic blood pressure (SBP) $\geq 140 \mathrm{mmHg}$ and/or current use of anti-hypertensive medication ${ }^{11}$.

The presence of diabetes was defined according to the criteria of the American Diabetes Association (ADA): fasting plasma glucose $\geq 126 \mathrm{mg} / \mathrm{dL}$ or use of oral hypoglycemic or insulin ${ }^{12}$.

Dyslipidemia was defined by abnormal levels of one or more of the following lipid blood components: triglycerides $\geq 150 \mathrm{mg} / \mathrm{dL}$, total cholesterol $\geq 200 \mathrm{mg} / \mathrm{dL}, \mathrm{LDL} \geq 160 \mathrm{mg} / \mathrm{dL}$, HDL in men $<40 \mathrm{mg} / \mathrm{dL}$ and in women $<50 \mathrm{mg} / \mathrm{dL}$, in addition to the history of use of medications to reduce these values. For individuals aged less than 20 years, the cut-off points are: triglycerides $\geq 130 \mathrm{mg} / \mathrm{dL}$, total cholesterol $\geq 170 \mathrm{mg} / \mathrm{dL}, \mathrm{LDL} \geq 130 \mathrm{mg} / \mathrm{dL}$ and $\mathrm{HDL} \leq 45 \mathrm{mg} / \mathrm{dL}^{13}$.

For the diagnosis of metabolic syndrome (MS), the I Brazilian Guideline of Diagnosis and Treatment of Metabolic Syndrome was used, which requires the presence of at least three of the following elements: waist diameter $>102 \mathrm{~cm}$ for men and $>88 \mathrm{~cm}$ for women; triglycerides $\geq 150 \mathrm{mg} / \mathrm{dL} ; \mathrm{HDL}<40 \mathrm{mg} / \mathrm{dL}$ for men and $<50 \mathrm{mg} / \mathrm{dL}$ for women; $\mathrm{SBP} \geq 130 \mathrm{mmHg}, \mathrm{DBP} \geq 85 \mathrm{mmHg}$ or use of anti-hypertensive; fasting glycemia $\geq 110 \mathrm{mg} / \mathrm{dL}$ or use of hypoglycemic ${ }^{14}$.

The dependent variable of the study (CKD) was defined according to the formulas of the Chronic Kidney Disease Epidemiology Collaboration (CKD-EPI), when GFR $<60 \mathrm{ml} / \mathrm{min} / 1.73 \mathrm{~m}^{2}$ and/or albuminuria $>29 \mathrm{mg} / \mathrm{g}^{15}$. 
The use of equations to estimate the GFR provides adjustments for the substantial variations regarding sex, age, body surface and ethnicity, characteristics that interfere in the production of creatinine. To this end, the validated equations of the Chronic Kidney Disease Epidemiology Collaboration (CKD-EPI) were used, described below:

Female:

Black skin color $\leq 0.7=166 \times(\text { serum creatinine } / 0.7)^{-0.329} \times 0.993^{\text {age }}$
Black skin color $>0.7=166 \times(\text { serum creatinine } / 0.7)^{-1.209} \times 0.993^{\text {age }}$
White skin color $\leq 0.7=144 \times(\text { serum creatinine } / 0.7)^{-0.329} \times 0.993^{\text {age }}$
White skin color $>0.7=144 \times(\text { serum creatinine } / 0.7)^{-1.209} \times 0.993^{\text {age }}$

Male:

Black skin color $\leq 0.9=163 \times(\text { serum creatinine } / 0.9)^{-0.411} \times 0.993^{\text {age }}$

Black skin color $>0.9=163 \times(\text { serum creatinine } / 0.9)^{-1.209} \times 0.993^{\text {age }}$

White skin color $\leq 0.9=141 \times(\text { serum creatinine } / 0.9)^{-0.411} \times 0.993^{\text {age }}$

White skin color $>0.9=141 \times(\text { serum creatinine } / 0.9)^{-1.209} \times 0.993^{\text {age }}$

The category "black skin color" included the individuals who self-declared black or brown.

In 2012, the categories of risk were defined for the progression of chronic kidney disease based on serum creatinine, with correction by formulas for obtaining GFR, and in albuminuria. In addition, the stage 3 of the CKD was divided in $3 \mathrm{a}$ and $3 \mathrm{~b}$. An important emphasis of the guidelines is the adoption of categories of CKD prognosis, classifying from low to high risk of progression of the acute renal injury for CKD and other complications ${ }^{15}$.

The data was analyzed using the Complex samples routines of the Statistical Package for the Social Sciences software (SPSS), version 20.0, for Windows. The natural weight of the design, the sample selection stratum, the primary sampling unit code (CEA) and the calibrated weight were maintained in the data files.

The data were analyzed in a descriptive and exploratory way to assess the distribution and characterize the studied population. The qualitative variables were described in absolute numbers and proportions. To analyze the differences between categorical variables, we used Pearson's chi-squared test.

A bivariate analysis was also performed in order to explore the association of the different variables with the object of study. Models of odds ratio estimated the magnitude of association between the dependent variable CKD and the independent variables. For multiple analysis, the variables included were the ones that showed a p value lower than 0.10 in the crude analysis, and the magnitude of the variables adjusted by the other significant variables was analyzed. The backward method was used in the selection of the variables in the multivariate analysis. Age and sex interactions with CKD were tested, with no effect changes observed. The significance level considered was $\alpha=0.05$.

All analysis considered the effect of the sampling design and the calibrated weights of the observations, and the results of the observations are demonstrated by "n" and the results considering the calibrated weights for extrapolation for the population by "expanded $\mathrm{n}(\mathrm{N})$ ". To this end, the pseudo maximum likelihood method (PML) was used, considering the sampling weights and the structural information of the sampling plan. The interferences were assessed by Wald statistics based on the sampling plan, along with the F distribution. 
Table 1. Prevalence by category of risk of the prognosis of CKD evolution assessed by GFR (estimated by the CKD-EPI formula) and albuminuria in older adults from Rio Branco, state of Acre, 2014.

\begin{tabular}{|c|c|c|c|c|c|c|c|c|c|c|c|}
\hline \multirow{3}{*}{\multicolumn{2}{|c|}{$\begin{array}{l}\text { Categories of risk } \\
\text { of CKD }\end{array}$}} & \multirow{2}{*}{\multicolumn{2}{|c|}{ Total }} & \multicolumn{6}{|c|}{ Albuminuria } & \multirow{2}{*}{\multicolumn{2}{|c|}{$\begin{array}{c}\text { CKD } \\
\text { (GFR* and albuminuria) }\end{array}$}} \\
\hline & & & & \multicolumn{2}{|c|}{ A1 $(<30)$} & \multicolumn{2}{|c|}{ A2 (30-299) } & \multicolumn{2}{|c|}{ A3 ( $\geq 300)$} & & \\
\hline & & $\mathbf{n}$ & N (\%) & $\mathbf{n}$ & $N(\%)$ & $\mathbf{n}$ & $\operatorname{Exp} N(\%)$ & $\mathbf{n}$ & $N(\%)$ & $\mathrm{n}$ & $\mathrm{N}(\%)$ \\
\hline 1 & $\geq 90$ & 296 & 7,982 (34.0) & $270^{\mathrm{a}}$ & $7,252(31.2)^{\mathrm{a}}$ & $19^{\mathrm{b}}$ & $518(2.2)^{\mathrm{b}}$ & $4^{c}$ & $116(0.5)^{c}$ & 23 & $634(2.7)$ \\
\hline 2 & $60-89$ & 547 & 12,407 (53.0) & $486^{a}$ & $10,982(47.3)^{\mathrm{a}}$ & $45^{\mathrm{b}}$ & $1,059(4.6)^{\mathrm{b}}$ & $11^{\mathrm{c}}$ & $260(1.1)^{c}$ & 56 & $1,319(5.7)$ \\
\hline $3 a$ & $45-59$ & 106 & $2,271(9.7)$ & $85^{\mathrm{b}}$ & $1,778(7.7)$ & $15^{c}$ & $358(1.6)^{c}$ & $6^{d}$ & $135(0.6)^{d}$ & 106 & $2,217(9.7)$ \\
\hline $3 b$ & $30-44$ & 26 & $552(2.4)$ & $19^{c}$ & $385(1.7)^{c}$ & $4^{d}$ & $93(0.4)^{d}$ & $3^{d}$ & $73(0.3)^{d}$ & 26 & $552(2.4)$ \\
\hline 4 & $15-29$ & 4 & $93(0.4)$ & $4^{\mathrm{d}}$ & $93(0.4)^{d}$ & - & - & - & - & 4 & $93(0.4)$ \\
\hline 5 & $<15$ & 4 & $111(0.5)$ & $1^{\mathrm{d}}$ & $24(0.1)^{\mathrm{d}}$ & $2^{\mathrm{d}}$ & $54(0.2)^{d}$ & $1^{\mathrm{d}}$ & $33(0.1)^{\mathrm{d}}$ & 4 & $111(0.5)$ \\
\hline Total & & 983 & $23,416(100.0)$ & 865 & $20,514(88.4)$ & 85 & $2,082(9.0)$ & 25 & 617 (2.6) & 219 & 4,979 (21.4) \\
\hline
\end{tabular}

$\mathrm{N}$ : expanded $\mathrm{n}$ from sampling weights and design; \%: proportion from $\mathrm{N}$; CKD: chronic kidney disease; GFR: glomerular filtration rate

* CKD-EPI formula: Chronic Kidney Disease Epidemiology Collaboration $\left(\mathrm{ml} / \mathrm{min} / 1.73 \mathrm{~m}^{2}\right)$.

${ }^{a}$ Low.

${ }^{b}$ Mild.

${ }^{c}$ Moderate.

${ }^{\mathrm{d}}$ High.

Table 2. Prevalence of CKD according to sociodemographic characteristics and life habits of older adults in Rio Branco, state of Acre, 2014.

\begin{tabular}{|c|c|c|c|c|c|c|c|c|c|}
\hline \multirow{3}{*}{ Variable } & \multirow{2}{*}{\multicolumn{2}{|c|}{ Total }} & \multicolumn{6}{|c|}{ CKD } & \multirow{3}{*}{ p } \\
\hline & & & \multicolumn{3}{|c|}{ Yes } & \multicolumn{3}{|c|}{ No } & \\
\hline & $\mathbf{n}$ & $\mathbf{N}$ & $\mathbf{n}$ & $\mathrm{N}$ & $\%$ & $\mathbf{n}$ & $\mathbf{N}$ & $\%$ & \\
\hline Sex & & & & & & & & & 0.519 \\
\hline Female & 577 & 12,496 & 123 & 2,570 & 20.6 & 454 & 9,926 & 79.4 & \\
\hline Male & 406 & 10,920 & 96 & 2,409 & 22.1 & 310 & 8,511 & 77.9 & \\
\hline Age group (years) & & & & & & & & & $<0.001$ \\
\hline $60-69$ & 475 & 13,394 & 75 & 2,134 & 15.9 & 400 & 11,260 & 84.1 & \\
\hline $70-79$ & 339 & 6,687 & 80 & 1,586 & 23.7 & 259 & 5,101 & 76.3 & \\
\hline 80 and more & 169 & 3,335 & 64 & 1,259 & 37.8 & 105 & 2,076 & 62.2 & \\
\hline Skin color & & & & & & & & & 0.158 \\
\hline White & 241 & 5,601 & 62 & 1,374 & 24.5 & 179 & 4,227 & 75.5 & \\
\hline Brown & 634 & 15,221 & 140 & 3,217 & 21.1 & 494 & 12,004 & 78.9 & \\
\hline Other & 108 & 2,594 & 17 & 388 & 15.0 & 91 & 2,206 & 85.0 & \\
\hline Education level* & & & & & & & & & 0.804 \\
\hline Higher education & 38 & 954 & 10 & 231 & 24.2 & 28 & 723 & 75.8 & \\
\hline High school & 112 & 2,828 & 21 & 528 & 18.7 & 91 & 2,300 & 81.3 & \\
\hline Elementary school & 360 & 8,721 & 76 & 1,807 & 20.7 & 284 & 6,914 & 79.3 & \\
\hline Illiterate/Literate & 465 & 10,712 & 109 & 2,344 & 21.9 & 356 & 8,368 & 78.1 & \\
\hline Marital status* & & & & & & & & & 0.011 \\
\hline Married & 365 & 9,144 & 80 & 1,994 & 21.8 & 285 & 7,150 & 78.2 & \\
\hline Single & 178 & 4,356 & 28 & 591 & 13.6 & 150 & 3,765 & 86.4 & \\
\hline Widow/Widower & 317 & 6,793 & 85 & 1,754 & 25.8 & 232 & 5,039 & 74.2 & \\
\hline Separated/Divorced & 117 & 2,980 & 25 & 616 & 20.7 & 92 & 2,365 & 79.3 & \\
\hline Physical activity & & & & & & & & & 0.153 \\
\hline Yes & 149 & 3,654 & 26 & 593 & 16.2 & 123 & 3,061 & 83.8 & \\
\hline No & 834 & 19,762 & 193 & 4,386 & 22.2 & 641 & 15,376 & 77.8 & \\
\hline Smoking & & & & & & & & & 0.148 \\
\hline Non-smoker & 282 & 6,696 & 71 & 1,618 & 24.2 & 211 & 5,078 & 75.8 & \\
\hline Ex-smoker & 537 & 12,541 & 119 & 2,689 & 21.4 & 418 & 9,852 & 78.6 & \\
\hline Smoker & 164 & 4,179 & 29 & 672 & 16.1 & 135 & 3,507 & 83.9 & \\
\hline Consumption of alcoholic beverage & & & & & & & & & 0.149 \\
\hline No & 857 & 20,138 & 185 & 4,131 & 20.5 & 672 & 16,007 & 79.5 & \\
\hline Yes & 80 & 2,175 & 23 & 600 & 27.6 & 57 & 1,575 & 72.4 & \\
\hline
\end{tabular}

$\mathrm{N}$ : expanded $\mathrm{n}$ from sampling weights and design; \%: proportion from $\mathrm{N} ; \chi^{2}=\mathrm{p}$ : Pearson's chi-squared test; CKD: chronic kidney disease

* The differences in relation to the total are due to the lack of information in the variable. 
This study meets the requirements of Resolution CNS 466/2012, which addresses ethics in research involving human beings, and was approved by the Research Ethics Committee of the Universidade Federal do Acre, under CAAE: 17543013.0.0000.5010.

\section{RESULTS}

The prevalence of CKD was of $21.4 \%$, with verified decreased GFR in $13.0 \%$ of older adults and the presence of albuminuria in $11.6 \%$. The prevalence of the prognosis with mild, moderate and high risk was, respectively, $14.5 \%, 4.9 \%$ and $2.1 \%$ (Table 1).

The presence of CKD was higher among octogenarian individuals, with a prevalence of almost $40.0 \%$, and among those declared widows/widowers, who showed a prevalence of $25.9 \%$, with statistically significant differences (Table 2).

In the analysis of the health conditions of older adults with CKD, 29.5\% reported considering their health bad or very bad, $26.4 \%$ were classified as obese, $24.0 \%$ had SAH and $22.7 \%$ had dyslipidemia. Diabetes obtained the highest prevalence, $41.5 \%$, and metabolic syndrome

Table 3. Prevalence of CKD according to health conditions in older adults in Rio Branco, state of Acre, 2014.

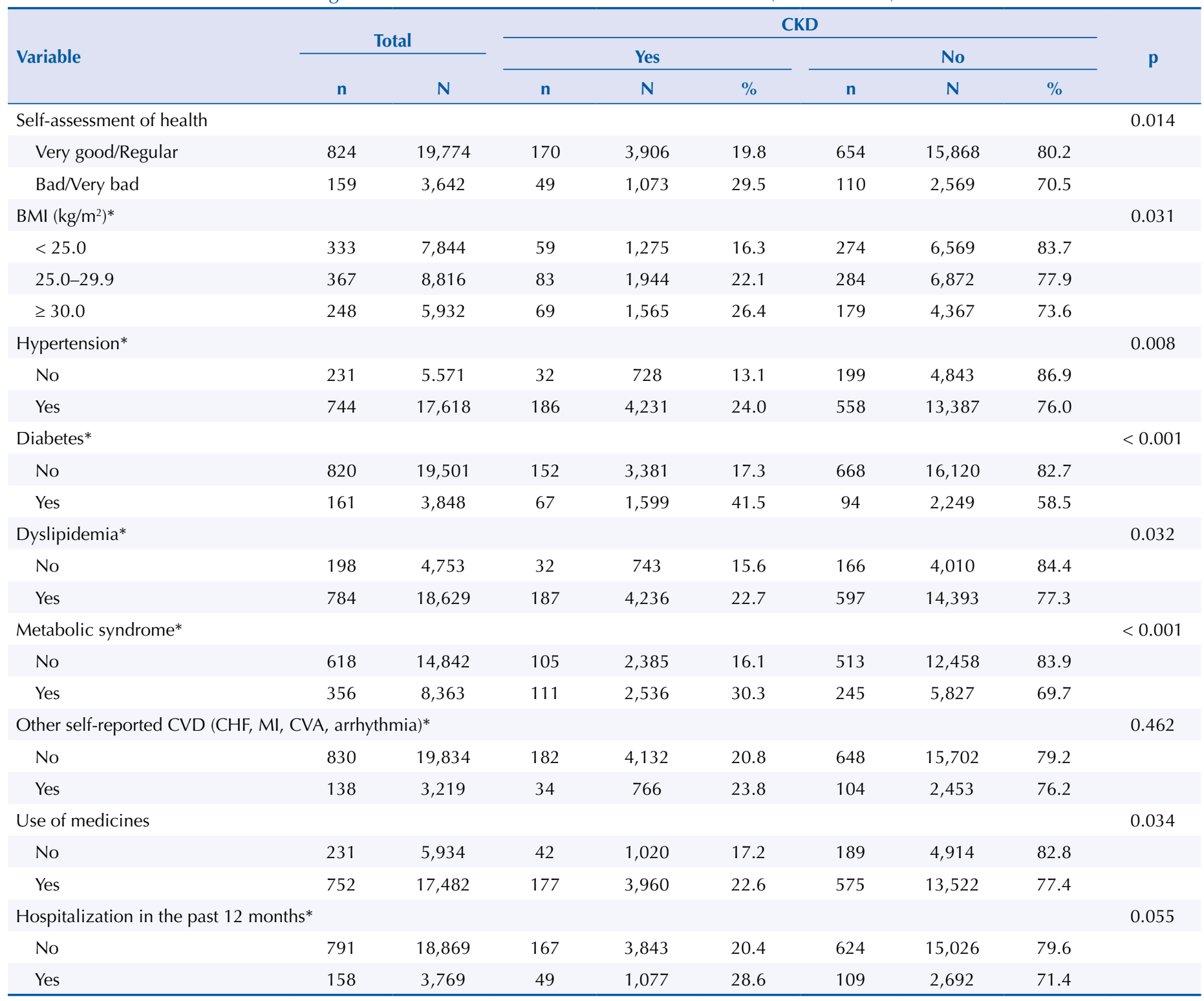

$\mathrm{N}$ : expanded $\mathrm{n}$ from the sampling weights and design; \%: proportion from $\mathrm{N} ; \chi^{2}=\mathrm{p}$ : Pearson's chi-squared test; BMI: body mass index; CVD: cardiovascular diseases; CHF: congestive heart failure; MI: myocardial infarction; CVA: cerebrovascular accident

* The differences in relation to the total are due to the lack of information in the variable. 
Table 4. Factors associated to CKD in older adults from Rio Branco, state of Acre, 2014.

\begin{tabular}{|c|c|c|}
\hline Variable & $\mathrm{OR}_{\text {crude }}(95 \% \mathrm{Cl})$ & $\mathrm{OR}_{\text {adjusted }}(95 \% \mathrm{Cl})$ \\
\hline \multicolumn{3}{|l|}{ Age group (years) } \\
\hline $60-69$ & 1 & 1 \\
\hline $70-79$ & $1.64(1.12-2.40)$ & $1.83(1.25-2.68)$ \\
\hline 80 and more & $3.20(2.24-4.57)$ & $3.99(2.70-5.91)$ \\
\hline \multicolumn{3}{|c|}{ Self-assessment of health } \\
\hline Very good/Regular & 1 & 1 \\
\hline Bad/Very bad & $1.70(1.12-1.58)$ & $1.79(1.10-2.91)$ \\
\hline \multicolumn{3}{|l|}{$\mathrm{BMI}\left(\mathrm{kg} / \mathrm{m}^{2}\right)$} \\
\hline$<25.0$ & 1 & 1 \\
\hline $25.0-29.9$ & $1.46(0.95-2.24)$ & $1.37(0.90-2.08)$ \\
\hline$\geq 30.0$ & $1.85(1.11-3.08)$ & $1.69(1.02-2.80)$ \\
\hline \multicolumn{3}{|l|}{ Use of medicines } \\
\hline No & 1 & 1 \\
\hline Yes & $1.41(1.03-1.94)$ & $0.70(0.43-1.14)$ \\
\hline \multicolumn{3}{|l|}{ Arterial hypertension } \\
\hline No & 1 & 1 \\
\hline Yes & $2.10(1.22-3.63)$ & $1.82(1.04-3.19)$ \\
\hline \multicolumn{3}{|l|}{ Diabetes } \\
\hline No & 1 & 1 \\
\hline Yes & $3.39(2.34-4.91)$ & $3.39(2.13-5.40)$ \\
\hline \multicolumn{3}{|l|}{ Dyslipidemia } \\
\hline No & 1 & 1 \\
\hline Yes & $1.59(1.04-2.43)$ & $1.43(0.87-2.37)$ \\
\hline \multicolumn{3}{|l|}{ Metabolic syndrome* } \\
\hline No & 1 & 1 \\
\hline Yes & $2.27(1.61-3.21)$ & $2.49(1.71-3.63)$ \\
\hline
\end{tabular}

BMI: body mass index; OR: odds ratio; $\mathrm{OR}_{\text {crude }}$ : crude analysis; $\mathrm{OR}_{\text {adusted }}$ : adjusted analysis by the variables with each other

* In the analysis of metabolic syndrome, BMI, dyslipidemia, arterial hypertension and diabetes.

was present in $30.3 \%$ of the people classified as having a CKD. The use of medications was reported by $22.6 \%$ of these older adults (Table 3 ).

Statistically significant differences were observed in the distribution of CKD in the variables self-assessment of health, obesity according to the BMI, SAH, diabetes and dyslipidemia. Except for the self-assessment of health, all are components of metabolic syndrome, also related. The current use of medications also showed statistically significant difference in the presence of CKD (Table 3).

The assessment of odds ratio with the introduction of potentially confusing variables observed a statistically significant association between CKD and age group, self-assessment of health, obesity, hypertension, diabetes and metabolic syndrome, even after adjustment. The model for MS analysis did not include the variables SAH and DM, since they already belong to the definer set of the syndrome (Table 4).

\section{DISCUSSION}

The prevalence of CKD was high in older adults, being associated with age, self-assessment of health as bad or very bad, obesity, diabetes and metabolic syndrome, even after adjustments. In this research, the incorporation of objective criteria to standardize the staging of CKD (use of GFR according to the formula CKD-EPI and the classification of albuminuria) favored the comparison with different locations ${ }^{15}$. 
The prevalence of $\mathrm{CKD}$ increases with advancing age ${ }^{16}$. The aging process results in reduced GFR, which is a normal biological phenomenon linked to cellular and organ senescence, resulting from the change in the volume of the kidney, with reduced number of nephrons, change in the vasoactive response and changes in the activity of the renin-angiotensin systems, associated to the cellular oxidative stress ${ }^{17}$. Another functional abnormality of aging is the increased permeability of the glomerular basement membrane, which allows the excretion of a larger number of proteins, including albumin, another factor that influences the increase of the prevalence of renal injury in older people ${ }^{18}$. The decline of renal function, which seems to start early in the second decade of life $\mathrm{f}^{19}$, was observed in this study, with increased prevalence of CKD in each surveyed age group, reaching $37.8 \%$ in octogenarians.

The high prevalence of older adults with CKD, especially those with 70 years or more, according to the criteria of the Kidney Disease: Improving Global Outcomes (KDIGO) 2012, has been questioned by researches who defend a new definition of CKD for older adults, not classifying individuals in stage $3 \mathrm{a}$ as sick, but only those with GFR $<45 \mathrm{ml} / \mathrm{min} / 1,73 \mathrm{~m}^{2}$ and the presence of albuminuria ${ }^{20}$. This proposal would reduce the prevalence of renal injury in this study.

It is worth noting that two-thirds of the elderly population show reduced GFR without complications related to health in most cases; however, the presence of chronic conditions such as hypertension and diabetes, associated to aging, may lead to the sharp decline of renal function, with increased prevalence of $\mathrm{CKD}^{21}$. Different mechanisms are related with the physiopathology of CKD associated to $\mathrm{SAH}$, including the deregulation of sodium content, renin-angiotensin system and the endothelial function ${ }^{22}$, which become more expressive with age.

In a national survey performed with 7,552 subjects in Italy, the prevalence of CKD in the age group from 60 to 69 years was $8.7 \%$, and in the group from 70 to 79, it was approximately $17.0 \%$, with hypertension associated to the disease $(\mathrm{OR}=1.55)^{23}$. In a population study in Poland with 2,413 participants, the prevalence in the age group of 60 to 79 years was $15.3 \%$, with a nearly twice as likely chance of the hypertensive individual being classified as having $\mathrm{CKD}^{24}$. In this study, hypertension was also positively associated with CKD.

In addition to hypertension, among the morbidities assessed in this research, diabetes obtained a greater association with CKD, which was also observed in other researches ${ }^{23,24}$. Among diabetics, the mechanisms involved in the renal lesion result in glomerular hyperfiltration with proteinuria - in most cases, glomerulosclerosis with reduced GFR ${ }^{25}$. In a study on mortality due to CKD in Rio Branco, diabetes and SAH were among the associated leading causes of death ${ }^{26}$.

In this study, bad and very bad self-assessment of health was also related to CKD. This assessment is useful as an overall measure of the health status in the general population, being consistent with the real state of health. In a population-based research performed in China, with individuals with 18 years or more, the presence of CKD resulted in a four times greater change of self-report to a poor health condition $(\mathrm{OR}=4.41 ; 95 \% \mathrm{CI} 3.20-6.07)^{27}$.

Obesity increases the risk of occurrence of diseases considered risk factors for the development of CKD, such as SAH and diabetes, in addition to acting in the progression of the stages of CKD by hyperfiltration, to meet the demands of the body weights and of the increase of the intra-glomerular pressure, which damages renal structures ${ }^{28}$. Among the older adults of this research, obesity defined by BMI, was associated with CKD.

The data analysis of 9,100 adults of the Chronic Renal Disease in Turkey (CREDIT) evidenced the association of CKD to obesity, determined by the BMI, and to metabolic syndrome $(\mathrm{OR}=1.32 ; 95 \% \mathrm{CI} 1.11-1.57)^{29}$. In this research, even after adjustment, the 
presence of CKD increased more than twice the chance the individual has of having metabolic syndrome.

One of the limitations of this research is the possible attenuation of the associations observed, due to the effect of survival among older adults. Another factor is the definition of CKD by the estimation of the GFR and albuminuria from a blood and urine punctual sample, since it is recognized that the confirmation of the disease occurs when the abnormality in GFR or albuminuria for a period of three months. In addition, the choice of more than one individual of a same household may result in the reduction of variability. It is necessary to emphasize, also, that the exclusion of individuals without physical or cognitive capacity to participate in the study may lead to errors in the estimation of the GFR, since these are more likely to reduce this rate.

Finally, the importance of population surveys stands out as an important source of information on the health of the older adult population, aimed at the definition of risk factors and the prevention of diseases or their complications. Finding the disease in its early stages among older adults must be a priority in Northern Brazil, which has an aging index that went from $8.2 \%$ in 1970 to $24.6 \%$ in 2010, in addition to the increase of chronic morbidities such as diabetes, $\mathrm{SAH}$ and obesity ${ }^{30}$, factors associated to CKD.

\section{REFERENCES}

1. Ojo A. Addressing the global burden of chronic kidney disease through clinical and translational research. Trans Am Clin Climatol Assoc. 2014 [cited 2017 Feb 1];125:229-46. Available from em: https://www.ncbi.nlm.nih.gov/pmc/articles/PMC4112688/

2. Hoerger TJ, Simpson SA, Yarnoff BO, Pavkov ME, Ríos Burrows N, Saydah SH, et al. The future burden of CKD in the United States: a simulation model for the CDC CKD Initiative. Am J Kidney Dis. 2015;65(3):403-11. https://doi.org/10.1053/j.ajkd.2014.09.023

3. Lebov JF, Valladares E, Peña R, Peña EM, Sanoff SL, Cisneros EC, et al. A population-based study of prevalence and risk factors of chronic kidney disease in León, Nicaragua. Can J Kidney Health Dis. 2015;2:6. https://doi.org/10.1186/s40697-015-0041-1

4. Arora P, Vasa P, Brenner D, Iglar K, McFarlane P, Morrison H, et al. Prevalence estimates of chronic kidney disease in Canada: results of a nationally representative survey. CMAJ. 2013;185(9):E417-23. https://doi.org/10.1503/cmaj.120833

5. Glassock RJ, Rule AD. Aging and the kidneys: anatomy, physiology and consequences for defining chronic kidney disease. Nephron. 2016;134(1):25-9. https://doi.org/10.1159/000445450

6. Stevens LA, Viswanathan G, Weiner DE. Chronic kidney disease and end stage renal disease in the elderly: current prevalence, future projections, and clinical significance. Adv Chronic Kidney Dis. 2010;17(4):293-301. https://doi.org/10.1053/j.ackd.2010.03.010

7. Stevens LA, Li S, Wang C, Huang C, Becker BN, Bomback AS, et al. Prevalence of CKD and comorbid illness in elderly patients in the United States: results from the Kidney Early Evaluation Program (KEEP). Am J Kidney Dis. 2010;55(3 Suppl 2):S23-33. https://doi.org/10.1053/j.ajkd.2009.09.035

8. Silva PLN. Calibration estimation: when and why, how much and how. Rio de Janeiro: IBGE; 2004. (Textos para Discussão. Diretoria de Pequisas).

9. Madeira JL, Simões CCS. Estimativas preliminares da população urbana e rural segundo as unidades da federação, de 1960/1980 por uma nova metodologia. Rev Bras Estat. 1972;33(129):3-11.

10. Amaral TLM, Amaral CA, Portela MC, Monteiro GTR, Vasconcellos MTL. Estudo das Doenças Crônicas (Edoc): aspectos metodológicos. Rev Saude Publica. 2019;53:8. http://dx.doi.org/10.11606/s1518-8787.2019053000847

11. Sociedade Brasileira de Cardiologia; Sociedade Brasileira de Hipertensão; Sociedade Brasileira de Nefrologia. VI Diretrizes brasileiras de hipertensão. Arq Bras Cardiol. 2010;95(1 Supl 1):1-51. https://doi.org/10.1590/S0066-782X2010001700001 
12. Sociedade Brasileira de Diabetes. Diretrizes da Sociedade Brasileira de Diabetes: 2013-2014. Oliveira JEP, Vencio S, organizadores. São Paulo: AC Farmacêutica; 2014 [cited 2017 Jan 15]. Available from: http://www.diabetes.org.br/images/pdf/diretrizes-sbd.pdf

13. Xavier HT, Izar MC, Faria Neto RJ, Assad MH, Rocha VZ, et al. V Diretriz Brasileira de Dislipidemias e Prevenção da Aterosclerose. Arq Bras Cardiol. 2013;101(4 Supl 1):1-20. https://doi.org/10.5935/abc.2013S010

14. Sociedade Brasileira de Hipertensão; Sociedade Brasileira de Cardiologia; Sociedade Brasileira de Endocrinologia e Metabologia; Sociedade Brasileira de Diabetes; Associação Brasileira para Estudos da Obesidade. I Diretriz Brasileira de Diagnóstico e Tratamento da Síndrome Metabólica. Arq Bras Cardiol. 2005;84 Supl 1:3-28. https://doi.org/10.1590/S0066-782X2005000700001

15. Levin A, Stevens PE, Bilous RW, Coresh J, De Francisco ALM, De Jong PE, et al. Kidney disease: improving global outcomes (KDIGO) CKD work group. Kidney disease: improving global outcomes (KDIGO) CKD work group. KDIGO 2012 clinical practice guideline for the evaluation and management of chronic kidney disease. Kidney Int Suppl. 2013;3(1):1-150. https://doi.org/10.1038/kisup.2012.73

16. Magalhães FG, Goulart RMM. Doença renal crônica e tratamento em idosos: uma revisão integrativa. Rev Bras Geriatr E Gerontol. 2015;18(3):679-92. https://doi.org/10.1590/1809-9823.2015.14132

17. Weinstein JR, Anderson S. The aging kidney: physiological changes. Adv Chronic Kidney Dis. 2010;17(4):302-7. https://doi.org/10.1053/j.ackd.2010.05.002

18. El Bahanasy RE, Mahrous OA, Salem MEA, El Batanony MA, Mourad WS, Kasemy ZA. The role of microalbuminuria in population screening for chronic kidney disease in an Egyptian village. Menoufia Med J. 2013;26(1):18-22. https://10.7123/01.MMJ.0000429484.86621.34

19. Coresh J, Selvin E, Stevens LA, Manzi J, Kusek JW, Eggers P, et al. Prevalence of chronic kidney disease in the United States. JAMA. 2007;298(17):2038-47. https://doi.org/10.1001/jama.298.17.2038

20. Glassock RJ, Delanaye P, El-Nahas M. Managing Chronic kidney disease in older people--reply. JAMA. 2016;315(3):307-8. https://doi.org/10.1001/jama.2015.15999

21. Kithas PA, Supiano MA. Hypertension and chronic kidney disease in the elderly. Adv Chronic Kidney Dis. 2010;17(4):341-7. https://doi.org/10.1053/j.ackd.2010.04.003

22. Hamrahian SM, Falkner B. Hypertension in chronic kidney disease. Adv Exp Med Biol. 2017;956:307-25. https://doi.org/10.1007/5584_2016_84

23. De Nicola L, Donfrancesco C, Minutolo R, Lo Noce C, Palmieri L, De Curtis A, et al. Prevalence and cardiovascular risk profile of chronic kidney disease in Italy: results of the 2008-12 National Health Examination Survey. Nephrol Dial Transplant. 2015;30(5):806-14. https://doi.org/10.1093/ndt/gfu383

24. Zdrojewski Ł, Zdrojewski T, Rutkowski M, Bandosz P, Król E, Wyrzykowski B, et al. Prevalence of chronic kidney disease in a representative sample of the Polish population: results of the NATPOL 2011 survey. Nephrol Dial Transplant. 2016;31(3):433-9. https://doi.org/10.1093/ndt/gfv369

25. Mrozikiewicz-Rakowska B, Maroszek P, Nehring P, Sobczyk-Kopciol A, Krzyzewska M, Kaszuba AM, et al. Genetic and environmental predictors of chronic kidney disease in patients with type 2 diabetes and diabetic foot ulcer: a pilot study. J Physiol Pharmacol. 2015 [cited 2017 May 25];66(5):751-61. Available from: http://www.jpp.krakow.pl/journal/archive/10_15/ pdf/751_10_15_article.pdf

26. Amaral TLM, Amaral CA, Miranda-Filho AL, Monteiro GTR. Tendência e causa múltipla de óbito por insuficiência renal crônica em município na Amazônia brasileira, 1986-2012. Cienc Saude Coletiva. 2018;23(11):3821-8. http://dx.doi.org/10.1590/1413-812320182311.29902016

27. Wu S, Wang R, Zhao Y, Ma X, Wu M, Yan X, et al. The relationship between self-rated health and objective health status: a population-based study. BMC Public Health. 2013;13:320. https://doi.org/10.1186/1471-2458-13-320

28. Kovesdy CP, Furth SL, Zoccali C; World Kidney Day Steering Committee. Obesity and kidney disease: hidden consequences of the epidemic. Kidney Int. 2017;91(2):260-2. https://doi.org/10.1016/j.kint.2016.10.019 
29. Arinsoy T, Deger SM, Ates K, Altun B, Ecder T, Camsari T, et al. Prevalence of Chronic kidney disease in Turkish adults with obesity and metabolic syndrome: a post hoc analysis from chronic renal disease in Turkey study. J Ren Nutr. 2016;26(6):373-9. https://doi.org/10.1053/j.jrn.2016.08.004

30. Ministério da Saúde (BR), Secretaria e Vigilância em Saúde, Departamento de Vigilância e Agravos não Transmissíveis e Promoção da Saúde. Vigitel Brasil 2014: vigilância de fatores de risco e proteção para doenças crônicas por inquérito telefônico. Brasília (DF); 2015 [cited 2017 Nov 29]. Available from: http://bvsms.saude.gov.br/bvs/publicacoes/vigitel_brasil_2014.pdf

Funding: Conselho Nacional de Desenvolvimento Científico e Tecnológico [CNPq - Call MCTI/CNPQ/ MS-SCTIE-DECIT 06/2013, for support to strategic research for the Health System by the Rede Brasileira de Avaliação de Tecnologias em Saúde (REBRATS - Brazilian Network of Assessment of Health Technologies), Process 401081/2013-3]; Fundação de Amparo à Pesquisa do Acre [FAPAC - Call PPSUS 001/2013, of the Research Program for SUS: shared health management (MS/CNPq/FAPAC/SESACRE), Process 6068-14-0000029].

Authors' Contribution: Conception and planning of the study: TLMA, CAA, GTRM. Data collection, analysis and interpretation: TLMA, CAA, GTRM, MTLV. Drafting or review of the manuscript: TLMA, CAA, GTRM, MTLV. All the authors approved the final version and take public responsibility for the content of the article.

Conflict of Interest: The authors declare no conflict of interest. 